\title{
Attitude of Coastal Rural Youths Towards Some Selected Modern Livestock Technologies
}

\author{
M. U. Rashid* and M. E. Uddin \\ Department of Agricultural Extension and Rural Development, Patuakhli Science and Technology University \\ (PSTU), Dumki, Patuakhali, Bangladesh \\ *Corresponding author and Email: murashidpstu@gmail.com
}

\begin{abstract}
A study was conducted to determine the attitude of the coastal rural youth towards some selected modern livestock technologies. Data were collected from randomly selected 91 youths of Patuakhali district using a structured interview schedule during 15 May to 31 May 2007. Coastal rural youths' attitude towards some selected livestock technologies was the dependent variable of the study. Ten selected individual characteristics of the respondents namely, age, education, family size, family farm size, family annual income, aspiration, innovativeness, extension media contact, agricultural knowledge and time spent in agricultural activities were considered as the independent variables of the study. Majority of the coastal rural youth (49.4 percent) had moderately favourable attitude, while 28.6 per cent had less favourable and 22 per cent had highly favourable attitude to modern livestock technologies. Among the ten selected independent variables aspiration, extension medial contact and agricultural knowledge had positive significant relationship with coastal youths' attitude towards some selected livestock technologies.
\end{abstract}

Keywords: Attitude, rural youth, livestock technologies

\section{Introduction}

There is a need to establish a meaningful relationship for the youth within the family and the community structure. It is also required to ensure that they are fruitfully employed (Ray, 1999). The world wide statistics indicate that over 200 million young people, or 18 per cent of all youth, live on less than one dollar a day, and 515 million on less than two dollars a day. Despite the fact that youth are receiving more education, youth unemployment in the world has increased to record levels. Youth unemployment at a total of 88 million is the highest in the Western Asia, North Africa and Sub-Saharan Africa, and consequently there is increased pressure on young people to compete in globalizing labour market (Anonymous, 2005).

Food security embraces food production, stability of supply and access to food. Livestock plays an important role in all three aspects. A significant contribution to food production is made through the provision of high-value protein-rich animal products. Animals indirectly support crop production through draught power and manure and thus, they help stabilize supply, and finally, they are the most significant source of income and store of wealth for smallholders, thereby providing access to food (Bahram et al., 2008) 
Youths can play significant role in the overall development of a country through their active and skilled youth power. About one third of the total population of Bangladesh is youth, which is near about four and quarter crores (DYD, 2004). By their dominant figure and energy, young people can make an immense contribution in nation building. They would be able to play an important role in building global food security and development. But unfortunately, many of the youth do not get the chance to fulfill that potential because of their unfavourable attitude formation. Lack of education, training and organizational program mostly make them unproductive (Ali and Anwar, 2000).

The total population in the coastal zone of Bangladesh is 36.83 million, of which 10.8 million is youth (WARPO, 2006). So, overall development of the country immensely depends upon the development of this region. Rural youths are closely involved in agriculture. Unemployment problem among the youth can be solved through initiating appropriate livestock technologies. Positive attitude formation to livestock technologies is an important prerequisite for adopting modern livestock technologies. Therefore, the present study was undertaken with the following specific objectives:

1. To determine the attitude of the coastal rural youth towards some selected livestock technologies. The selected technologies are-goat rearing and poultry cum fish culture.

2. To describe some characteristics of the coastal rural youths. The characteristics are-age, education, family size, family farm size, family annual income, aspiration, innovativeness, extension media contact, agricultural knowledge and time spent in agricultural activities.

3. To explore the relationship of the selected characteristics of the coastal rural youths with their attitude towards some selected livestock technologies.

\section{Methodology}

The population of the study covered all the rural youths including both male and female youth of the three-selected villages namely, Santosdi, Boga Bandar and Chargarabdi under Patuakhali district. Lists of 450 youths were prepared in advance as the population of the study. From that population, 20 per cent respondents were selected randomly. Hence, the sample size was ninety-one (91). Data were collected by the researchers. A structured interview schedule was used for collection of data during 15 May to 31 May, 2007.

\subsection{Variables of the study}

Coastal rural youths' attitude towards some selected modern livestock technologies was the dependent variable of the study. The researcher selected two modern livestock technologies viz. goat rearing and poultry cum fish culture. Besides, ten selected individual characteristics of the coastal rural youths namely age, education, family size, family farm size, family annual income, aspiration, innovativeness, extension media contact, agricultural knowledge and time spent in agricultural activities were considered as the independent variables of the study.

\subsection{Measurement of the dependent variable (attitude)}

Attitude of the coastal rural youth towards some selected modern agricultural technologies was ascertained through a 5-point-Likert type scale having 4-statements for each technology. Hence, agreement on twelve $(3 \times 4=12)$ statements were ascertained as 'strongly agree', 'agree', 'undecided', 'disagree' and 'strongly disagree' with the corresponding scores of 4, 3, 2, 1 and 0 . Thus, for a respondent the attitude score could rang from 0 to 32 , where 0 indicates most unfavourable attitude and 32 indicates most favourable attitude. 


\section{Results and Discussion}

\subsection{Some basic features of individual characteristics}

Table 1 provides some basic statistics of individual characteristics of the respondents which are self-explanatory. It was found that most of the respondents were older(29-35 Yrs) had secondary education, comprising medium family, had small family farm size, having medium family annual income, had medium aspiration, moderate innovativeness, medium extension media contact, medium agricultural knowledge and moderate time spent in agricultural activities.

\subsection{Attitude of the coastal rural youths towards some selected livestock technologies}

Attitude of the coastal rural youths towards some selected livestock technologies was categorized into three as 'less favourable attitude', 'moderately favourable attitude' and 'favourable attitude' according to their mean attitude score (22.73) and standard deviation (5.24). Data in Table 2 indicate that highest proportion (49.45 percent) of the coastal rural youths had moderately favourable attitude while 28.57 and 21.97 percent youth showed less favourable and favourable attitude, respectively towards selected livestock technologies.

Agriculture in the coastal region is underdeveloped due to several reasons such as high soil salinity, flooding, cyclone, tidal surges etc. So the young people always have a tendency to migrate in big cities like Dhaka, Chittagong, Khulna which was probably reflected in their attitude formation as more than two third of the respondents had either less or moderately favourable attitude towards the selected livestock practices. This is graphically shown in Fig 1.

\subsection{Relationship of selected individual characteristics of the coastal rural youth and their attitude towards some selected livestock technologies.}

Table 3 shows that aspiration, extension media contact and agricultural knowledge of the coastal rural youth had positive and significant relationship with their attitude towards selected livestock technologies. On the other hand age, education, family size, family farm size, family annual income, innovativeness and time spent in agricultural activities had no significant relationship with their attitude. Rashid (2004) also found similar results in his study on usefulness of training received by the youths from the Youth Training Center of Mymensingh.

Natural disaster like cyclone, tidal surges, river bank erosion, tsunami and salinity problems are common phenomenon in coastal area. Livelihood of coastal people is very often damaged by these natural disasters. Natural disasters not only damage the crop and livestock resources of coastal people but also hundreds of lives of human being. Hence coastal youth always try to be educated and look for salaried job in other parts of the country. This may be the reason why other variables show no significant relationship with the attitude of coastal rural youth towards some selected livestock technologies.

\subsection{Features of the selected technologies according to attitude responses}

Data in Table 4 show the degree of agreement and disagreement of the respondents towards two selected livestock technologies, particularly to the statements related to them.

It is revealed from Table 4 that coastal youths showed highly positive attitude to the statements those are related to the efficiency and economic potentials of the selected technologies. At the same time, they possessed less positive attitude with the social aspects of the selected technologies.

In coastal areas livestock and agriculture are not as developed as in the other parts of the country. Due to lack of modern communication and transportation system diffusion rate of modern livestock technologies is very slow here. As a result, coastal people do not consider agriculture and livestock as dignified ways of earning livelihood though they are aware of the potentialities of modern livestock technologies. 
Table 1. Descriptive statistics of the independent variables

\begin{tabular}{|c|c|c|c|c|c|c|c|c|}
\hline \multirow{2}{*}{$\begin{array}{c}\text { Selected } \\
\text { characteristics }\end{array}$} & \multirow{2}{*}{ Categories } & \multicolumn{2}{|c|}{ Respondent } & \multirow{2}{*}{$\begin{array}{l}\text { Scoring } \\
\text { method }\end{array}$} & \multicolumn{2}{|c|}{ Range } & \multirow{2}{*}{ Mean } & \multirow{2}{*}{$\mathrm{SD}$} \\
\hline & & No. & $\%$ & & Min & Max & & \\
\hline \multirow[t]{3}{*}{ Age } & "Younger youth(15-22) & 22 & 24.17 & \multirow{3}{*}{ Years } & \multirow{3}{*}{15} & \multirow{3}{*}{35} & \multirow{3}{*}{28.63} & \multirow{3}{*}{6.25} \\
\hline & Youth(23-30) & 25 & 27.47 & & & & & \\
\hline & Older youth(29-35) & 44 & 48.35 & & & & & \\
\hline \multirow[t]{5}{*}{ Education } & Illiterate $(0)$ & 5 & 5.49 & \multirow{5}{*}{$\begin{array}{l}\text { Years of } \\
\text { schooling }\end{array}$} & \multirow{5}{*}{0} & \multirow{5}{*}{14} & \multirow{5}{*}{7.20} & \multirow{5}{*}{3.66} \\
\hline & Semi-literate $(0.5)$ & 5 & 5.49 & & & & & \\
\hline & Primary(1-5) & 22 & 24.17 & & & & & \\
\hline & Secondary(6-10) & 49 & 53.84 & & & & & \\
\hline & Higher secondary \& above $(>10)$ & 10 & 10.98 & & & & & \\
\hline \multirow[t]{3}{*}{ Family size } & Small family(2-4) & 22 & 24.17 & \multirow{3}{*}{ Number } & \multirow{3}{*}{3} & \multirow{3}{*}{10} & \multirow{3}{*}{6.48} & \multirow{3}{*}{2.73} \\
\hline & Medium family(5-8) & 53 & 58.24 & & & & & \\
\hline & Large family(9-20) & 16 & 17.58 & & & & & \\
\hline \multirow{4}{*}{$\begin{array}{l}\text { Family } \\
\text { size }\end{array}$} & Marginal(up to o.20) & 6 & 6.59 & \multirow{4}{*}{ Hectare } & & & & \\
\hline & Small farmer(0.21-1.0) & 40 & 43.95 & & 0.06 & 16.76 & 1.51 & 2.00 \\
\hline & Medium farm(1.1-3.0) & 34 & 37.36 & & & & & \\
\hline & Large farm(above 3.0) & 11 & 12.08 & & & & & \\
\hline Family annual & Low income(4-50) & 33 & 36.26 & & & & & \\
\hline & Medium(51-120) & 47 & 51.64 & $\begin{array}{l}\text { Rated } \\
\text { score }\end{array}$ & 4.00 & 507 & 77.41 & 75.16 \\
\hline & High income(>120) & 14 & 15.38 & & & & & \\
\hline Aspiration & Low $(4-12)$ & 18 & 19.78 & & & & & \\
\hline & Medium(13-18) & 52 & 57.14 & $\begin{array}{l}\text { Rated } \\
\text { score }\end{array}$ & 4 & 30 & 15.64 & 4.04 \\
\hline & $\operatorname{High}(19-30)$ & 21 & 23.07 & & & & & \\
\hline Innovativeness & Less innovative(0-9) & 19 & 20.87 & & & & & \\
\hline & Moderate(10-20) & 52 & 57.14 & Rated & 0 & 26 & 14.95 & 6.34 \\
\hline & Highly innovative(21-28) & 20 & 21.97 & & & & & \\
\hline Extension & Low $(0-10)$ & 21 & 23.07 & & & & & \\
\hline media contact & Medium(11-18) & 49 & 53.84 & $\begin{array}{l}\text { Rated } \\
\text { score }\end{array}$ & 0 & 32 & 15.01 & 6.55 \\
\hline & $\operatorname{High}(19-42)$ & 21 & 23.07 & & & & & \\
\hline Agricultural & Low(0-20) & 14 & 15.38 & & & & & \\
\hline knowledge & Medium(21-27) & 53 & 58.24 & $\begin{array}{l}\text { Rated } \\
\text { score }\end{array}$ & 14 & 30 & 24.62 & 3.84 \\
\hline & $\operatorname{High}(28-30)$ & 24 & 26.37 & & & & & \\
\hline Time spent in & Less(0-23) & 19 & 20.87 & & & & & \\
\hline $\begin{array}{l}\text { agricultural } \\
\text { activities }\end{array}$ & Moderate(24-90) & 56 & 61.53 & $\begin{array}{l}\text { Rated } \\
\text { score }\end{array}$ & 0 & 182 & 59.24 & 37.43 \\
\hline & More(91-182) & 16 & 17.58 & & & & & \\
\hline
\end{tabular}


Table 2. Distribution of the coastal rural youths according to their attitude towards the selected livestock technologies.

\begin{tabular}{l|c|c|c|c}
\hline \multirow{2}{*}{ Categories of attitude } & \multicolumn{3}{c}{ Coastal rural youth (N=91) } \\
\cline { 2 - 4 } & Number & Percent & Mean & SD \\
\hline \hline Less favourable (less than 19) & 26 & 28.57 & \\
Moderately favourable (19-28) & 45 & 49.45 & 22.73 & 5.24 \\
Favourable (greater than 28) & 20 & 21.97 & \\
Total & 91 & 100 & \\
\hline
\end{tabular}

Table 3. Relationship of selected individual characteristics of the coastal rural youth and their attitude towards some selected livestock technologies.

\begin{tabular}{ll}
\hline Selected individual characteristics & Correlation coefficient (r) \\
\hline \hline Age & $-0.065^{\mathrm{NS}}$ \\
Education & $0.042^{\mathrm{NS}}$ \\
Family size & $0.065^{\mathrm{NS}}$ \\
Family farm size & $-0.073^{\mathrm{NS}}$ \\
Family annual income & $-0.025^{\mathrm{NS}}$ \\
Aspiration & $0.392^{* *}$ \\
Innovativeness & $0.139^{\mathrm{NS}}$ \\
Extension media contact & $0.263^{*}$ \\
Agricultural knowledge & $0.344^{* *}$ \\
Time spent in agricultural activities & $0.047^{\mathrm{NS}}$ \\
\hline
\end{tabular}

$* *=$ Significant at 1 percent level, $* *=$ Significant at 5 per cent level

NS $=$ Non-significant 
Table 4. Attitude frequency of coastal youths related to selected livestock technologies.

\begin{tabular}{|c|c|c|c|c|c|c|c|c|}
\hline \multirow{2}{*}{$\begin{array}{l}\text { Sl. } \\
\text { no }\end{array}$} & \multirow[t]{2}{*}{ Statements related to the technology } & \multicolumn{5}{|c|}{ Attitude frequency } & \multirow{2}{*}{$\begin{array}{l}\text { Total } \\
\text { score }\end{array}$} & \multirow[t]{2}{*}{ Mean } \\
\hline & & SA & A & UD & $\mathrm{D}$ & SD & & \\
\hline $\mathbf{A}$ & Goat rearing & & & & & & & \\
\hline $\begin{array}{l}1 . \\
(+)\end{array}$ & $\begin{array}{l}\text { Unemployment problems can be } \\
\text { prevented through goat rearing }\end{array}$ & $35 \times 5$ & $42 \times 4$ & $5 \times 3$ & $7 \times 2$ & $2 \times 2$ & 376 & 4.13 \\
\hline $\begin{array}{l}2 . \\
(-)\end{array}$ & $\begin{array}{l}\text { Goat damages the crops of the neighbors } \\
\text { and act as an appeal of discord. Hence } \\
\text { goat should not be reared. }\end{array}$ & $20 \times 1$ & $25 \times 2$ & $3 \times 3$ & $33 \times 4$ & $10 \times 5$ & 261 & 2.86 \\
\hline $\begin{array}{l}3 . \\
(+)\end{array}$ & $\begin{array}{l}\text { Market price of goat is high and raring } \\
\text { of goat is easy. Hence, it is profitable. }\end{array}$ & $44 \times 5$ & $32 \times 4$ & $5 \times 3$ & $5 \times 2$ & $5 \times 1$ & 378 & 4.15 \\
\hline $\begin{array}{l}4 . \\
(-)\end{array}$ & $\begin{array}{l}\text { Goat raring is not a honorable job for } \\
\text { educated people }\end{array}$ & $16 \times 1$ & $15 \times 2$ & $10 \times 3$ & $30 x 4$ & $20 x 5$ & 296 & 3.25 \\
\hline B & Poultry cum fish culture & & & & & & & \\
\hline $\begin{array}{l}1 . \\
(+)\end{array}$ & $\begin{array}{l}\text { Fish, meat and egg can be harvested at } \\
\text { the same time so, poultry cum fish } \\
\text { culture is profitable }\end{array}$ & $60 \times 5$ & $25 \times 4$ & $2 \times 3$ & $2 \times 2$ & $2 \times 1$ & 412 & 4.52 \\
\hline $\begin{array}{l}2 . \\
(+)\end{array}$ & $\begin{array}{l}\text { In this method no additional food is need } \\
\text { to be supplied in pond. }\end{array}$ & $42 \times 5$ & $35 \times 4$ & $8 \times 3$ & $5 \times 2$ & $1 \times 1$ & 385 & 4.23 \\
\hline $\begin{array}{l}3 . \\
(-)\end{array}$ & $\begin{array}{l}\text { The fishes feed with poultry litter has a } \\
\text { less demand in the market. }\end{array}$ & $10 \times 1$ & $10 \times 2$ & $7 \times 3$ & $38 \times 4$ & $26 \times 5$ & 333 & 3.65 \\
\hline $\begin{array}{l}4 . \\
(-)\end{array}$ & $\begin{array}{l}\text { Both fish and poultry business is not an } \\
\text { honorary work. }\end{array}$ & $6 \times 1$ & $15 \times 2$ & $3 \times 3$ & $37 \times 4$ & $30 \times 5$ & 343 & 3.76 \\
\hline
\end{tabular}

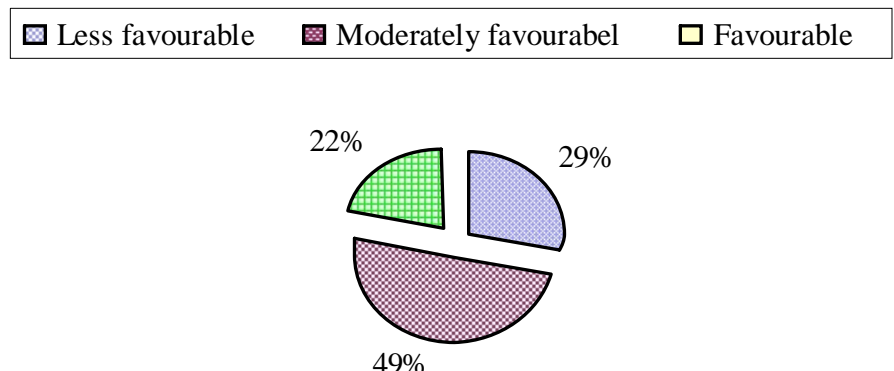

Fig. 1. Coastal youth's attitude towards some selected livestock technologies. 


\section{Conclusions and Recommendations \\ 4.1. Conclusions}

Most of the coastal youths showed moderately favourable attitude towards the selected modern livestock technologies, while the remaining youths have less favorable and highly favourable attitude in almost equal proportion. Among the selected variables aspiration, extension media contact and agricultural knowledge had positive significant relationship with attitude to selected modern livestock technologies while other variables such as age, education, family size, family farm size, family annual income, innovativeness and time spent in agricultural activities had non-significant relationship with attitude to livestock technologies.

\subsection{Recommendations}

1. Extension media can play vital role in the diffusion of modern livestock technologies. So, different mass and interpersonal media should be employed for changing attitude of the coastal rural youths.

2. Knowledge on livestock plays an important role in changing the attitude of coastal rural youth towards positive direction. Hence, GOs and NGOs should initiate different training programs to develop the knowledge of coastal rural youths, particularly on livestock issues.

3. In coastal region livestock rearing is not considered as an honorable profession though it is profitable and effective to drive away poverty. Government should take special motivation programs to change the social perception of coastal people towards livestock technologies.

\section{References}

Ali, M. A. and Anwar, A. B. M. 2000. Anticipated Problem Confrontation of the unemployed Rural youth for undertaking Selected Agricultural Income Generating Activities for the Employment. Bangladesh. Journal of Extension Education, 11\&12 (1\&2):61-68.

Anonymous. 2005. United Nations World Youth Report.http:www.un.org/esa/socdev/unyin/ wyr05.htm

Bahram,L.A. and M.S. Haque. 2008. Livestock as Source of Wealth and Food Security. http://www. thefinancialex- pressbd.com/search

DYD. 2004. Proshikhan karjakram, Department of Youth Development, Ministry of youth and Sports, Government of the People Republic of Bangladesh, Dhaka.

Rashid, M.U. 2004. Usefulness of Training Received by the Youths from the Youth Training Center of Mymensingh. M. S. (Ag. Ext. Ed.) Thesis. Department of Agricultural Extension Education, Bangladesh Agricultural University, Mymensingh.

Ray, G. L. 1999. Extension Communication and Management. Naya Prokash, Calcutta, India.

WARPO. 2006. State of the Coast, Ministry of Water Resources, Government of the People's Republic of Bangladesh, Dhaka. 